\title{
Robust volumetric models for supporting the management of secondary forest stands in the Southern Brazilian Atlantic Forest
}

\author{
LAIO Z. OLIVEIRA ${ }^{1}$, ALINE R. KLITZKE ${ }^{1}$, ALFREDO C. FANTINI ${ }^{2}$, HEITOR \\ F. ULLER ${ }^{1}$, JEAN CORREIA ${ }^{3}$ and ALEXANDER C. VIBRANS ${ }^{1}$ \\ ${ }^{1}$ Universidade Regional de Blumenau/FURB, Departamento de Engenharia Florestal, \\ Rua São Paulo, 3250, Itoupava Seca, 89030-000 Blumenau, SC, Brazil \\ ${ }^{2}$ Universidade Federal de Santa Catarina/UFSC, Departamento de Fitotecnia, Rodovia \\ Admar Gonzaga, 1346, Itacorubi, 88040-900 Florianópolis, SC, Brazil \\ ${ }^{3}$ ERD Consultoria Ambiental, Rua 1, 371, Centro, 89760-000 Itá, SC, Brazil
}

Manuscript received on February 1, 2018; accepted for publication on June 8, 2018

\begin{abstract}
The majority of Atlantic Forest fragments in Southern Brazil are second-growth forests dominated by fast-growing species with considerable market-value timber. Nevertheless, volume prediction models are scarce, especially to estimate tree total volume (i.e., stem plus branches). This study approached the issue through the following aims: to fit and select stem and total volume models (generic and species-specific) using data from 288 harvested trees in a management operation, and to fit generic and species-specific bark factors. The power model embedding diameter at breast height $(D)$ and tree stem or total height $(H)$ presented the greatest prediction strength for both stem and total tree volume. Models including only $D$ to predict total tree volume were similar to double-entry models regarding goodness-of-fit. Therefore, they may be useful in the context of subtropical closed-canopy forests, where the difficulty and uncertainty in $H$ measurements are not trivial. Species-specific models fitted for Miconia cinnamomifolia (DC) Naudin. and Hyeronima alchorneoides Allemão surpassed generic models only for the former species. Nevertheless, the prediction improvement should offset the eventual extra efforts implied in the collection of reliable samples of these species. Finally, bark factors stood as a satisfactory tool for inside bark mean volume estimation.
\end{abstract}

Key words: Forest inventory, Mata Atlântica, modelling, regression.

\section{INTRODUCTION}

Among all Brazilian vegetation domains, the Atlantic Forest suffers the greatest impact from human activities driving forest fragmentation and degradation (Ribeiro et al. 2009). The fragments' extent varies widely within the states where the

Correspondence to: Laio Zimermann Oliveira

E-mail: laiozoliveira@gmail.com
Atlantic Forest is found. In this regard, Santa Catarina, in Southern Brazil, is privilegedapproximately $29 \%$ of its territory is covered by native forests (Vibrans et al. 2013), which in turn is divided into three main forest types/subdomains: evergreen rainforest (ERF), Araucaria forest, and seasonal deciduous forest (Klein 1978). In this state, forests are usually very fragmented, with $80 \%$ smaller than 50 ha. The ERF covers $40.5 \%$ 
of its 29,282 $\mathrm{km}^{2}$ original extension, the largest in proportion among the three forest types (Vibrans et al. 2013). Notwithstanding, most of these remnants $(\sim 95 \%)$ are composed by second-growth forests, where pioneer and early secondary species dominate the successional process (Siminski and Fantini 2004, Schorn and Galvão 2006).

In this context, fast-growing species, such as Hyeronima alchorneoides Allemão, Miconia cinnamomifolia (DC) Naudin., Nectandra spp., and Ocotea spp., produce good quality timber, making secondary forest management attractive for land owners (Fantini et al. 2016, Siminski et al. 2016). Moreover, several authors agree on the potential benefits of pure or mixed plantations of suchlike species (Klein 1980, Schuch et al. 2008, Coradin et al. 2011). Both approaches would indeed reconcile the misunderstood mutually exclusive conflicting purposes of conservation, on the one hand, and use of forest resources in the region, on the other (Montagnini and Jordan 2005). Tailored planning of such a win-win solution would require a set of tools, including timber volume, biomass, and carbon stock estimation models.

Wood volume is one of the most essential pieces of information in the development of sustainable management programs. In forestry, regression models fitted to field data regarding measured tree volume and predictor variables such as diameter at breast height $(D)$ and tree or stem height $(H)$ prove to be feasible tools to estimate individual tree volume. Regression models may synthesize the relationship among variables and are hence adopted to predict a variable of interest on the basis of other subjects to an easier collection (Picard et al. 2012). Elsewhere, volumetric models have been developed for several purposes in Brazil, ranging from local to broader usages, fitted for a single species or for a group of species making up a particular forest type. Indeed, models were fitted for species with local economic interest like Mimosa scabrella Benth. (Machado et al. 2008) and
Ocotea porosa Nees \& Mart. (Santos et al. 2012), as well as for species that produce tannin, oil, and cork (Scolforo et al. 2008). For instance, Barreto et al. (2014) developed volumetric models for a community forest management project in the state of Pará using data from 132 trees of 23 commercial species. In turn, Vibrans et al. (2015) fitted generic and species-specific stem volume models for three forest types in Santa Catarina using data of 2,127 trees with diameters ranging from 10 to $76 \mathrm{~cm}$.

Despite the availability of volumetric models in the literature, there is a lack of models to predict individual tree total volume (i.e., stem plus branches). The data for model fitting is usually obtained through destructive methods, i.e., tree harvesting (e.g., Scolforo et al. 2008). However, legal restrictions and operational constraints in protected native forests may forbid the harvesting of trees, thus impeding data collection. A usual workaround is sampling collection by means of tree climbing, yet a viable alternative to gather stem volume data (e.g., Vibrans et al. 2015). Partly, this could be the explanation for the scarcity of total tree volume models for the Atlantic Forest subdomains in Brazil. To account for this, in this study we built on the research carried out by a consortium of universities and the state environmental agency on a secondary forest management controlled pilot in Santa Catarina (Fantini et al. 2016). This trial compiled a unique data collection from a large sample of harvested trees of species occurring in secondary forest fragments. As mentioned above, this kind of data is not easily accessible for either physical or regulation limitations regarding forest inventory techniques.

Hence, the objectives of the present study were (i) to fit generic and species-specific stem and total (i.e., stem plus branches) volume models using a robust cross-validation statistical procedure; (ii) to compare the performance of generic and species-specific models in predicting the volume of abundant and economically relevant species, 
namely Miconia cinnamomifolia and Hyeronima alchorneoides; (iii) to further examine the statistical implications of distinct relationships between dendrometric variables in volume models; and (iv) to provide generic and species-specific bark factors to generate inside bark volume estimates.

\section{MATERIALS AND METHODS}

\section{STUDY AREA}

The study site comprises 42 ha located in the state of Santa Catarina, Southern Brazil (26 32'01's; $49^{\circ} 02^{\prime} 30^{\prime \prime} \mathrm{W}$ ), within the ERF region (Figure 1) (Klein 1978, Oliveira-Filho et al. 2015). The site is covered mainly by a 35 -year-old second-growth forest, unmanaged for the last 30 years, resulting from succession after the abandonment of pastures and partially enriched with typical species of such forests in the region. According to Silva et al.
(2015), this forest has a density of $1,807.6$ trees $\mathrm{ha}^{-1}(D \geq 5 \mathrm{~cm})$ and basal area of $32.3 \mathrm{~m}^{2} \mathrm{ha}^{-1}$; $H$. alchorneoides and $M$. cinnamomifolia are the dominant species, contributing to $23.2 \%$ and $6.5 \%$ of the basal area, respectively.

According to the Köppen classification, the study site is influenced by the Cfa climate typesubtropical mesothermal humid climate with a hot summer and without a dry season (Alvares et al. 2013). The rainfall is evenly distributed throughout the year, with an annual average of 1,900 mm; the average annual temperature ranges from 19.1 to $20.0{ }^{\circ} \mathrm{C}$ (Pandolfo et al. 2002). The study site altitude above sea level ranges from 205 to 430 m. An association of two soil types predominates in the study site: moderate A Tb haplic Cambisol and moderate A Litholic Neosol; both may present argillaceous texture (Embrapa 2004).

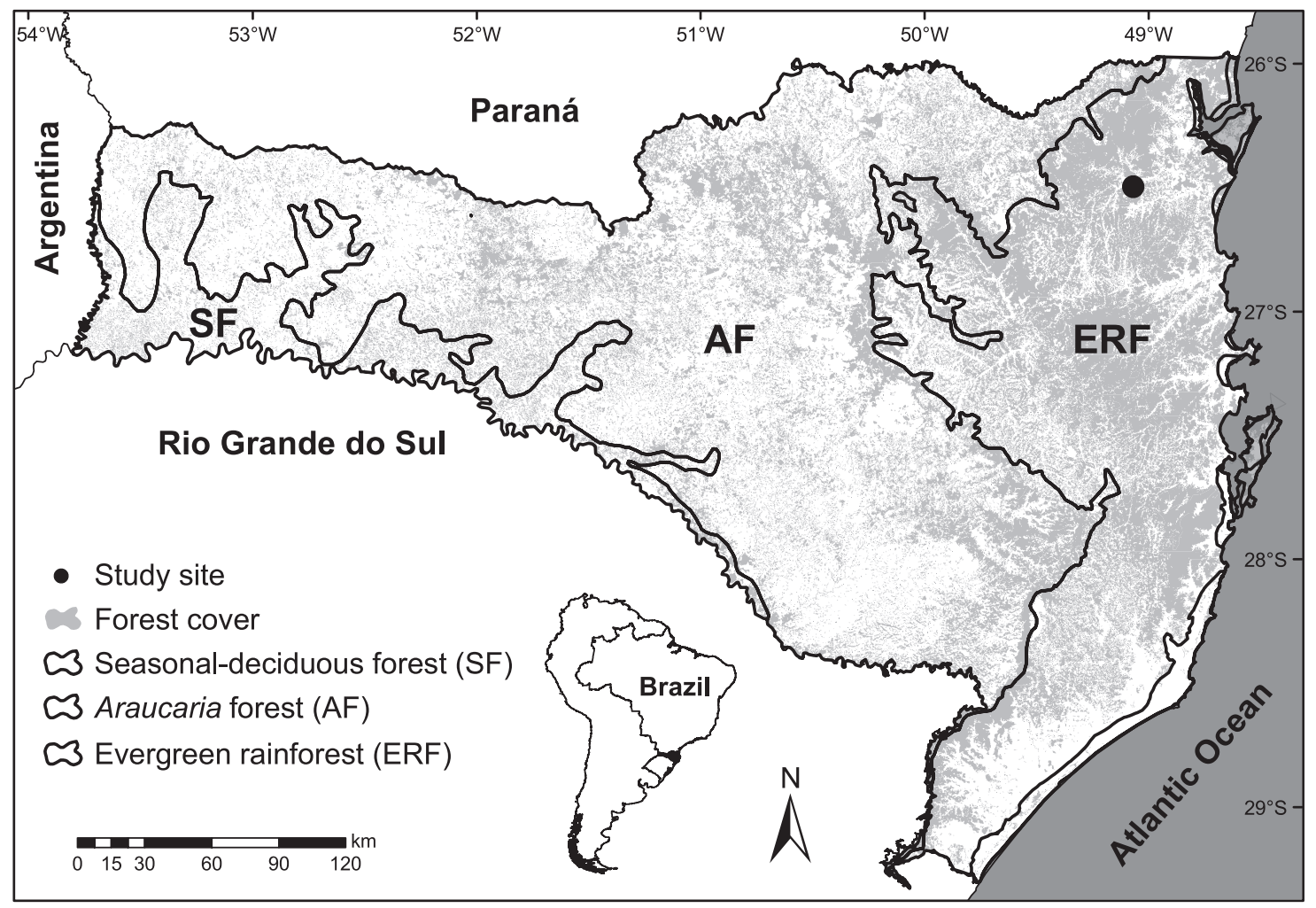

Figure 1 - Santa Catarina state, main forest types (Klein 1978), forest cover (Fundação S.O.S. Mata Atlântica 2009), and location of the study site. 


\section{DATA COLLECTION}

The total (i.e., stem plus branches) and stem volume $(V)$ of 288 felled trees from 31 families and 65 species were determined by use of the Smalian's formula (Avery and Burkhart 2015). The diameter at $1.3 \mathrm{~m}$ from the ground $(D)$ ranged from 5.4 to $56.0 \mathrm{~cm}$; the total tree height $\left(H_{\mathrm{t}}\right)$ ranged from 2.5 to $33 \mathrm{~m}$, and the stem height $\left(H_{\mathrm{s}}\right)$ ranged from 1.3 to $25.2 \mathrm{~m}$. The stem diameter was measured at the heights of $0.1,0.3,0.7,1.0,1.3,2.0$, and $3.0 \mathrm{~m}$ and consecutively at every meter until the upper end, which was defined by a significant bifurcation. The diameter of each branch at every meter from its base up to the diameter top limit of $5 \mathrm{~cm}$ was also measured. Diameters were measured using a diameter tape or a caliper. When using a caliper, two cross-sectional measurements were recorded. The tree bark thickness was measured using a digital caliper at the same points where the diameter had been measured. The total and stem heights were measured using a tape. In total, the 288 trees added up to $168.3 \mathrm{~m}^{3}$ of inside bark volume, out of which $58.1 \mathrm{~m}^{3}(34.5 \%)$ corresponded to branches $\geq 5.0 \mathrm{~cm}$.

\section{FITTING AND SELECTING GENERIC MODELS}

Ten generic models were fitted (Table I) to predict individual tree (i) outside bark stem volume $\left(\mathrm{m}^{3}\right)$ and (ii) outside bark total volume $\left(\mathrm{m}^{3}\right)$. Each model was fit to a randomly selected $70 \%$ subset $(n=202)$ from the entire dataset $(n=288)$. The remaining subset $(n=86)$ was used to assess model performance and, subsequently, to select the best models. Influential observations (i.e., outliers and leverage points) were investigated through the association of the Cook's distance-calculated for each observation in the fitting subsets-and the $F$ distribution percentile with $p$ and $n-p$ degrees of freedom, where $p$ is the number of regression parameters, and $n$ is the number of observations in the fitting subset. Observations scoring $F>0.50$ were regarded as influential and were removed (Neter et al. 1996).

After ordinary least squares model fitting, the uncertainty associated to the regression parameters estimation was assessed through the percent relative standard error (PRSE) (Eq. 1) (Sileshi 2014). The models' bias (Eq. 2), adjusted coefficient of determination $\left(\mathrm{R}^{2}\right)$, root mean squared error (RMSE, Eq. 3), mean absolute percentage error (MAPE, Eq. 4) as per Sileshi (2014), and the corrected Akaike's information criterion (AICc, Eq. 5) were calculated. The original scale of the response variable was used in all metrics. The $\mathrm{R}^{2}$ may be denoted as pseudo- $\mathrm{R}^{2}$ $\left(\mathrm{R}^{2 *}\right)$ when calculated for nonlinear models, as its underlying assumptions are not completely fulfilled (Anderson-Sprecher 1994). The procedure was repeated 1,000 times, from which the mean values of the regression parameters and their PRSE were determined, together with the mean values of the goodness-of-fit metrics (bias, RMSE, MAPE, AICc). In this cross-validation approach, the metrics may be noted as follows:

$\operatorname{PRSE}(\%)=\frac{1}{R} \sum_{R=1}^{R} \frac{S E\left(\hat{\theta}_{k}\right)}{\left|\hat{\theta}_{k}\right|} \times 100$

$\operatorname{Bias}(\%)=\frac{1}{R} \sum_{R=1}^{R} \frac{100}{n} \sum_{i=1}^{n} \frac{\hat{V}_{i}-V_{i}}{V_{i}}$

$R M S E=\frac{1}{R} \sum_{R=1}^{R}\left(\frac{\sum_{i=1}^{n}\left(V_{i}-\hat{V}_{i}\right)^{2}}{n}\right)^{1 / 2}$

$\operatorname{MAPE}(\%)=\frac{1}{R} \sum_{R=1}^{R} \frac{100}{n} \sum_{i=1}^{n} \frac{\left|V_{i}-\hat{V}_{i}\right|}{V_{i}}$

$A I C c=\frac{1}{R} \sum_{R=1}^{R}\left(n \cdot \ln (S S E)-n \cdot \ln (n)+2 p+\frac{2 p(p+1)}{n-p-1}\right)($ Eq. 5)

where $\hat{\theta}_{k}=k$ th estimated regression parameter; $S E=$ standard error; $V_{i}=$ observed volume of the 
$i$ th tree; $\hat{V}_{i}=$ predicted volume for the $i$ th tree; $n=$ number of trees used in the model selection procedure; $R=$ number of iterations, i.e., 1,$000 ; p$ $=$ number of regression parameters; and $S S E=$ sum of squared errors of the regression.

The selection of the best models was supported by the Akaike weights (Wagenmakers and Farrell 2004, Sileshi 2014), denoted by $w$ (AICc). Likewise, the PRSE of the best performance models were checked. Based on Sileshi (2014), a PRSE $>25 \%$ threshold was set to account for nontrivial uncertainty in the parameter estimation that should be evaluated ${ }^{1}$. When a given parameter of the best models yielded PRSE $>25 \%$, it was eventually dropped off in model fitting. Subsequently, the performance metrics were recalculated. Baskerville's (1972) correction factor (BCF) was applied to the predictions derived from linearized power models (i.e., the predicted volume was multiplied by the $\mathrm{BCF}$ ). The $\mathrm{BCF}$ is given by $\exp \left(\sigma_{\text {res }}^{2}\right)^{0.5}$, where $\sigma_{\text {res }}^{2}$ is the residual variance.

The predictions and residuals generated by the selected models were evaluated by observed vs. predicted values scatter plot inspection, hereafter denoted as 1:1 plot. The residuals $\left(\mathrm{m}^{3}\right)$ were likewise plotted and weighted by their respective observed values ( $y$-axis) vs. the predicted values ( $x$-axis) for evaluating uncommon patterns of residual distribution.

\section{FITTING AND SELECTING SPECIES-SPECIFIC MODELS}

Analogously, species-specific models were fitted for the two main species in the study site, namely $M$. cinnamomifolia $(n=29 ; D$ range: $14.0-56.0 \mathrm{~cm}$; $H_{\mathrm{t}}$ range: $15.2-27.3 \mathrm{~m} ; H_{\mathrm{s}}$ range: $\left.4.6-18.1 \mathrm{~m}\right)$ and $H$. alchorneoides $\left(n=53 ; D\right.$ range: $6.2-46.9 \mathrm{~cm} ; H_{\mathrm{t}}$ range: $6.5-27.8 \mathrm{~m} ; H_{\mathrm{s}}$ range: $2.5-25.2 \mathrm{~m}$ ). Due to the smaller sample sizes, the leave-one-out cross-

\footnotetext{
1 The significance of a given regression parameter is attained if PRSE $\leq 50 \%$, considering a sample with 30 degrees of freedom and $\alpha=0.05$ (Moser and Oliveira 2017).
}

validation approach was chosen. The models' bias $(\%), \mathrm{R}^{2 *}$, MAPE (\%), RMSE, AICc, and $w(\mathrm{AICc})$ were reported. The performances of the best generic model for stem and total volume were compared by applying them using each 'leftout' observation. Specific and generic models were compared through joint $95 \%$ confidence intervals of their parameters built using the 'ellipse' package in R. The ANOVA for nested models (Picard et al. 2012) was eventually applied to examine dendrometric relationships in the volume models; we calculated the relative importance of the predictor variables by using the 'relaimpo' package in R to assess their role in explaining the response variable in the stem and total volume models. To check the collinearity between predictor variables, the variance inflation factor (VIF) was calculated by the use of the 'car' package in $\mathrm{R}$.

\section{DEVELOPING AND VALIDATING BARK FACTORS}

Six bark factors were developed to estimate the inside bark total volume and stem volume of all species $(n=288)$, total volume and stem volume of $M$. cinnamomifolia $(n=29)$, and total volume and stem volume of $H$. alchorneoides $(n=53)$. The mean bark factor was estimated as the ratio between the inside bark volume and the outside bark volume. To evaluate the reliability of this approach-i.e., using bark factors for attaining mean inside bark volume estimates-the following steps were taken: (i) apply the best fitted volumetric model to the dataset; (ii) multiply the estimates by the respective bark factor; (iii) compare the mean volume generated in step (ii) with the observed mean inside bark volume through $95 \%$ confidence intervals for the mean paired difference using the standard $t$ distribution procedure. 


\section{RESULTS AND DISCUSSION}

\section{GENERIC MODELS}

The generic models for stem volume presented RMSE ranging from 0.08 to $0.15 \mathrm{~m}^{3}$ and MAPE ranging from 9.7 to $44.8 \%$. The model 10 presented the best performance; it yielded RMSE $=0.07$ $\mathrm{m}^{3}$ and MAPE $=9.7 \%$, and the uncertainty in the estimates of its parameters was small (PRSE $<5 \%$; Table I). The model showed positive bias, although it was close to zero $(1.1 \%)$. The $1: 1$ plot of the residuals revealed a good adjustment of the model to the data, and no evidence of strong heteroskedasticity was discernible.

The generic models for total tree volume presented inferior performance compared to the stem volume models. Their RMSE ranged from 0.17 to $0.20 \mathrm{~m}^{3}$ and MAPE ranged from 16.0 to $72.3 \%$. The greatest performance was achieved by model 4 according to the $w$ (AIC) (Table I). However, we chose not to rely solely on this metric, as the model yielded a MAPE of $30.7 \%$ and bias of $-12.7 \%$. Additionally, its parameters yielded a PRSE value greater or close to $30 \%$ due to the evident collinearity between the terms $D^{2}$ and $D^{2} H$. Because of these results, we evaluated models 3,9 , and 10 more closely, as they outperformed the others. The intercept of model 3 rendered PRSE $>50 \%$; therefore, we dropped it off and fitted the model again. The three models presented similar performance regarding RMSE and MAPE; models 9 and 10 presented slightly smaller MAPE. The uncertainty in the estimates of the parameters of these models may be considered acceptable (PRSE $<25 \%$ ) according to the standards proposed by Sileshi (2014). Finally, we may indicate model 10 as the most reliable among the three, because the compound term $D^{2} H$-included in models 3 and 9-may generate great leverage observations and therefore should be avoided (Sileshi 2014). Some degree of heteroskedasticity was noticeable, although the weighted residual plots showed evenness along the range of predicted values (Figure 2).
The overall quality of the models may be considered satisfactory, thus providing useful volume estimation tools in forest management operations in the Southern Brazilian ERF. The stem volume models outperformed the total tree volume models, as expected. Stem volume data are usually more homogeneous (i.e., less variability) than total tree volume data due to the fact that stems' geometrical attributes are better addressed by a combination of $D$ and stem $H$. Although the models to estimate total tree volume showed an inferior performance, they are still useful, especially facing the lack of such models for native species in the ERF and elsewhere in Brazil. As stated above, the destructive nature of such a data collection process partially explains the scarcity of models, although efforts could target standing tree measurements for building models to predict total tree volume for native species, in the line of Scolforo et al. (2008) in Minas Gerais state. The subject is more than critical when the wood volume of the crown is proportionally large in relation to the total tree volume. As a matter of fact, in our study, the branches $(\geq 5 \mathrm{~cm})$ represented $34.5 \%$ of the trees' total volume. This impressive amount of wood is not to be neglected in management systems conducted in secondary forests; it may well be used as firewood or for coal production. Indeed, the wood of M. cinnamomifolia and $H$. alchorneoides provides a calorific value comparable to Eucalyptus species (Brand et al. 2013, Carvalho et al. 2014).

Generic models to estimate tree total volume using only $D$ as the predictor variable presented an acceptable performance, with MAPE values smaller than 20\% (e.g., models 7 and 8). Models 7 and 8 presented quite similar prediction strength compared to model 10, which includes $D$ and $H$ (see Table I). In the case of generic models that estimate stem volume using only $D$ as a predictor, the MAPE values were greater than $25 \%$. Indeed, stem volume models for tropical species that do not include stem $H$ may yield a mean squared error 


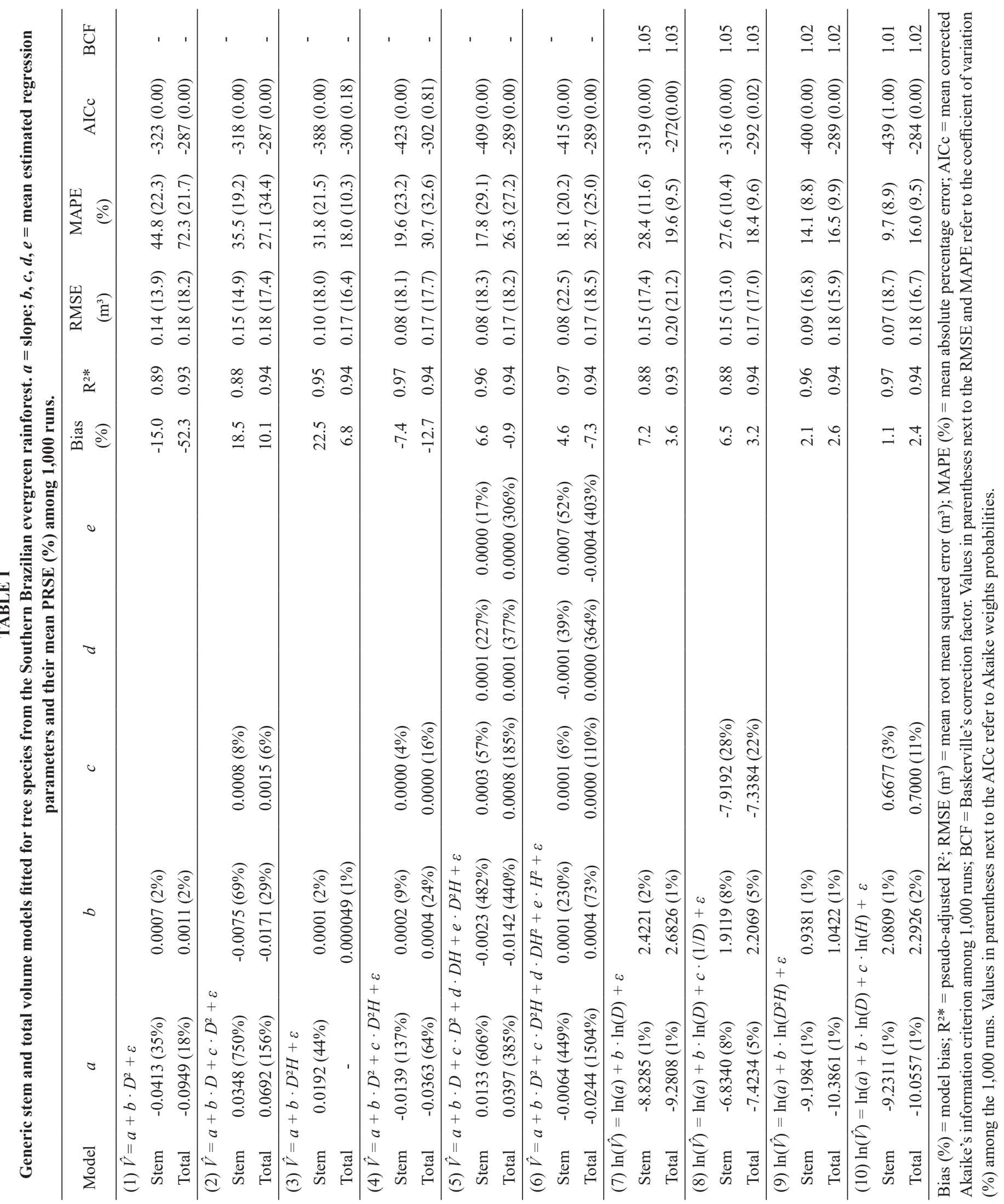



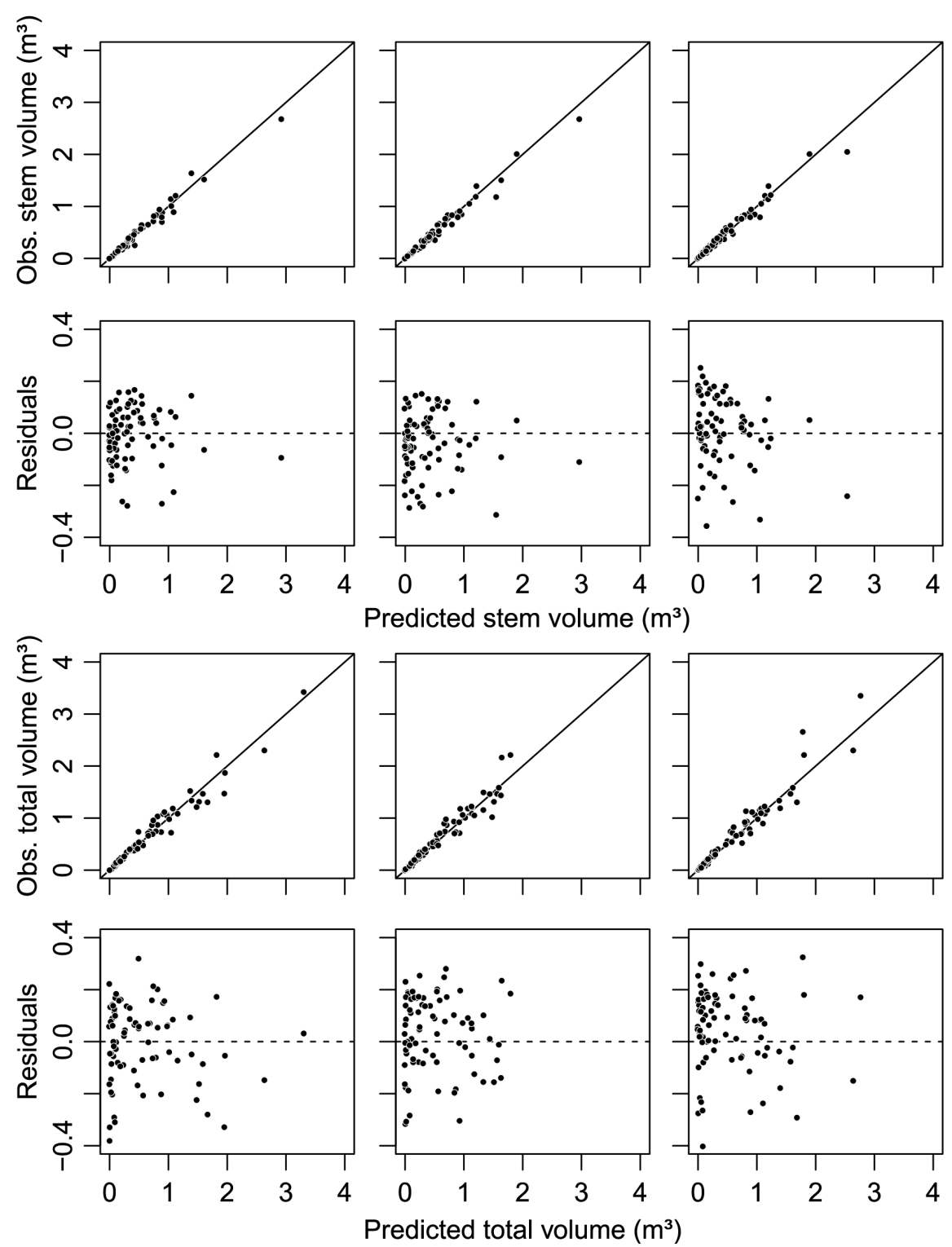

Figure 2 - Observed vs. predicted values generated by model 10 for stem and total volume. The plots are based on three independent iterations of the model fitting algorithm.

twice as great as models including both $D$ and $H$ (Brandeis et al. 2005). Accordingly, Feldpausch et al. (2012) reported that pantropical biomass models including $H$ outperformed models not including it. Facing these results, we conjecture that models using only $D$ to predict tree total volume are useful because precise height measurement in (sub)tropical dense forests is unfeasible in most situations or too expensive. In addition, the measurement of $H$ might represent a new source of uncertainty in volume or biomass predictions (Segura and Kanninen 2005, Temesgen et al. 2015). In fact, studies addressing the uncertainty in the predictions yielded by volumetric models using visually estimated or model-predicted tree heights as inputs would be useful (e.g., McRoberts et al. 2016).

In regards to methodological aspects, our study exposed a neglected topic highlighted by Sileshi (2014): models with collinear or non-explicative terms may yield parameters with large standard 
error, despite the eventual satisfactory performance conveyed by metrics such as RMSE and AIC (e.g., see models 5 and 6 in Table I for a clear example). Therefore, we strongly suggest the use of PRSE, standard errors, or confidence intervals of the parameters in model selection. Accordingly, models with nonsignificant parameters (i.e., not statistically different from zero) should be discarded. The PRSE should be evaluated considering the remarks of Picard et al. (2015) and Moser and Oliveira (2017), especially when adopting the parameter exclusion threshold suggested by Sileshi (2014). Reporting at least one of the aforementioned statistics is mandatory, as stated in the guidelines provided by Jara et al. (2015).

\section{SPECIES-SPECIFIC MODELS}

Not surprisingly, for both species, stem volume models using $D$ and $H$ outperformed models using only $D$ (Tables II and III). The latter models yielded RMSE ranging from 0.15 to $0.37 \mathrm{~m}^{3}$ and MAPE > $20 \%$. For M. cinnamomifolia, only two specific stem volume models ( 9 and 10) performed better than the generic stem volume model (model 10) in the leaveone-out procedure. The generic model yielded bias $=-2.6 \%, \mathrm{MAPE}=8.65 \%, \mathrm{RMSE}=0.07 \mathrm{~m}^{3}$, and $\mathrm{AICc}=-150$. Model 10 fitted for $M$. cinnamomifolia presented the best performance considering all metrics (Table II). The joint confidence intervals of its parameters did not overlap the ones built for the generic stem volume model. We therefore conjectured that the models were not equivalent, even though differences in their predictions in the 1:1 plot are subtle (Figure 3).

For $H$. alchorneoides, none of the specific stem volume models outperformed the generic stem volume model applied for this species. Only model 10 presented similar performance to the generic model, and the joint confidence intervals built for their parameters overlapped. The generic model showed a slightly better performance than the best specific model (10); it yielded bias $=-0.3 \%, \mathrm{MAPE}=7.5 \%$, RMSE $=0.05 \mathrm{~m}^{3}$, and AICc $=-310$. Nevertheless, the $1: 1$ plot revealed that the differences between the specific model and the generic model were almost unperceivable (Figure 3).

According to the $w(\mathrm{AICc})$, the best specific total volume model for both species was model 7, which included only $\ln (D)$ as the predictor variable (Tables II and III). However, models using $D$ and $H$, such as models 9 and 10, outperformed model 7 regarding the MAPE, although the parameter associated with $\ln (H)$ in model 9 yielded PRSE > $25 \%$ for both species (see the discussion below). In most cases, the generic model presented inferior performance according to the metrics, even though the $1: 1$ plots revealed similar patterns regarding their predictions (Figure 3).

Heteroskedasticity in the residuals was observable, especially for $H$. alchorneoides. The megaphone pattern is expected in biological data, as the magnitude of the residuals increases with the increase in the magnitude of the predictor variables (Picard et al. 2012). However, heteroskedasticity is an issue only when the estimation of confidence intervals for predictions is required (Neter et al. 1996, Picard et al. 2012).

The comparison between generic and speciesspecific models revealed important findings. For species with characteristic and regular architecture like M. cinnamomifolia, specific models might be useful for attaining better predictions. Specific models were more accurate for $M$. cinnamomifolia than for $H$. alchorneoides, possibly because the former species has a more regular architecture. Nonetheless, the better performance of speciesspecific models may not justify extra efforts demanded in data collection of reliable samples, even for species with great management potential, for which extra accurate volume prediction would be helpful. As a word of caution, we point out that the two species considered in our study represented together $28.5 \%$ of the trees in the dataset. 


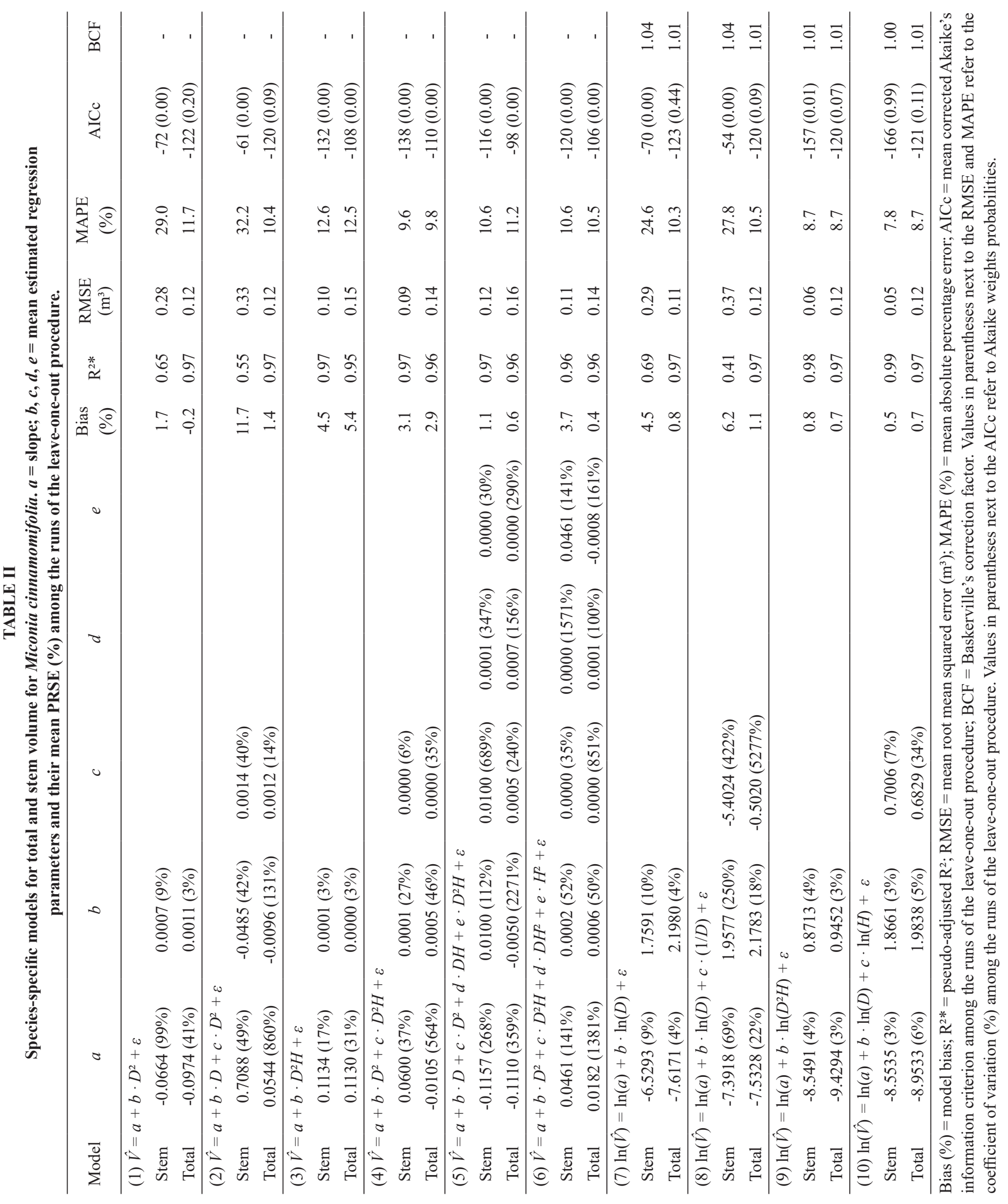




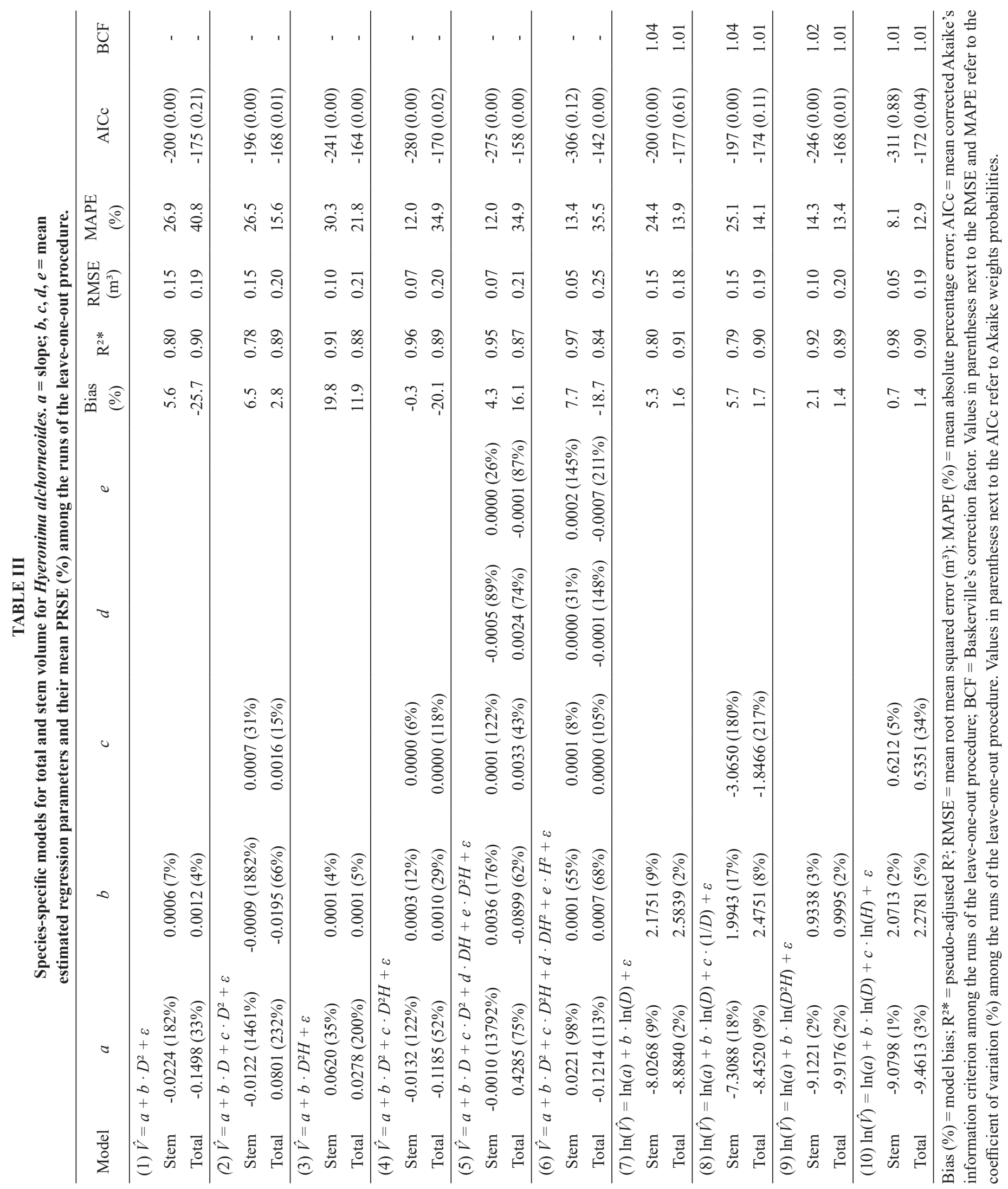



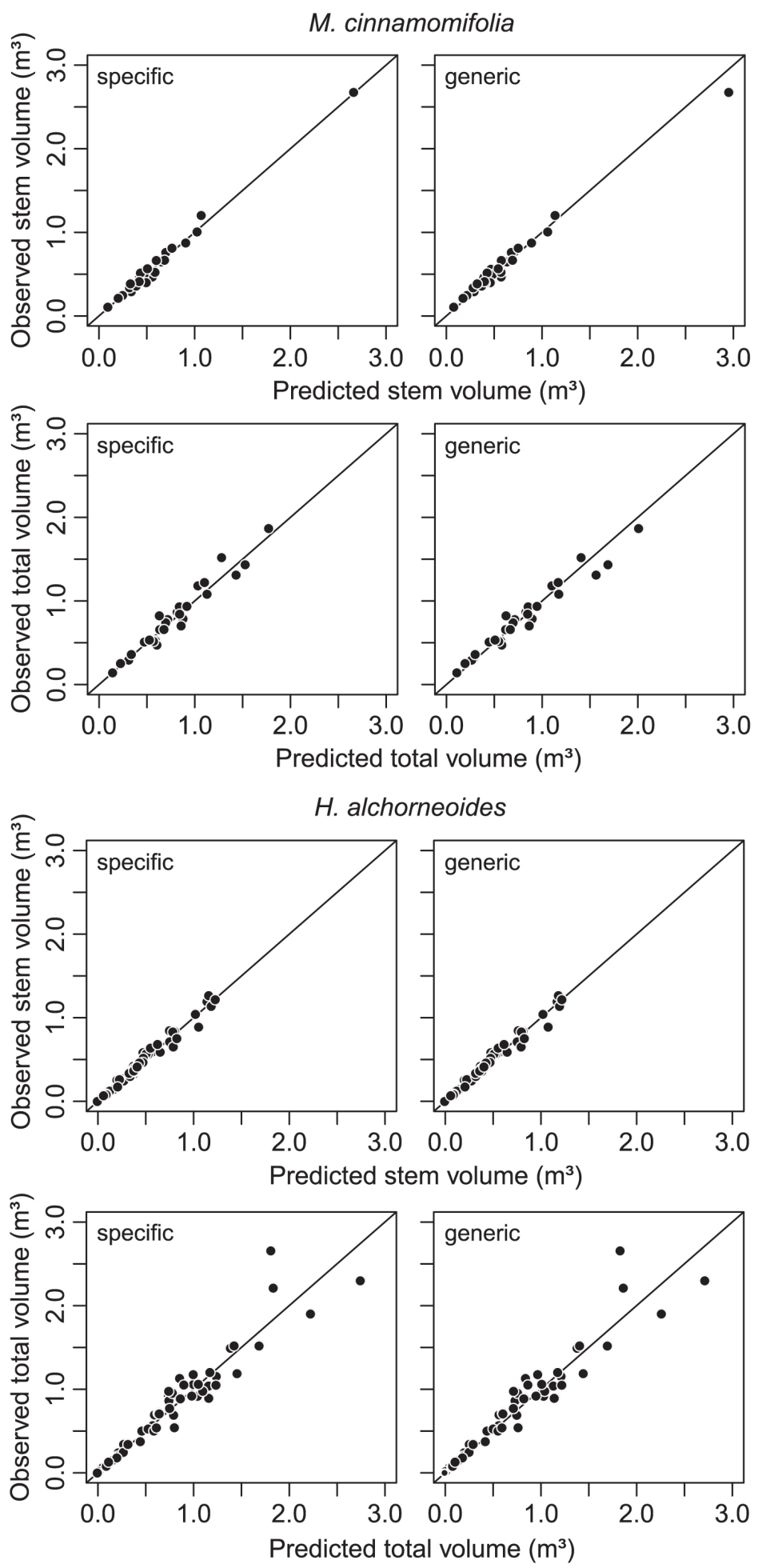

Figure 3 - Observed vs. predicted values generated by the best specific and generic stem and total tree volume models for M. cinnamomifolia and $H$. alchorneoides. 
EXAMINING DENDROMETRIC RELATIONSHIPS IN VOLUME MODELS

We further investigated why the models with two predictor variables $(D$ and $H$ ) failed to outperform the single predictor variable $(D)$ models for $M$. cinnamomifolia and $H$. alchorneoides. In the case of the best species-specific stem model $[\ln (V)=$ $\ln (a)+b \cdot \ln (D)+c \cdot \ln (H)+\varepsilon]$, a weak linear relationship was found between $D$ and stem $H$, as observed for $H$. alchorneoides ( $r=0.14, p=0.31$ ) (Figure 4). This finding implies that each variable might be regarded as independent in explaining the variation of $V$. As the two variables describe the geometrical form of the stem, a double-entry model is expected to perform better. The decomposition of the explained variance of $\ln (V)$ by $\ln (D)$ and $\ln (H)$ in the model $\ln (V)=\ln (a)+b \cdot \ln (D)+c \cdot \ln (H)+$ $\varepsilon$ fitted for $H$. alchorneoides yielded $\mathrm{R}^{2 *}{ }_{\ln (D)}=0.86$ and $\mathbf{R}^{2 *}{ }_{\ln (H)}=0.13$. With small collinearity between predictor variables $(\mathrm{VIF}=1.03)$, the standard errors of the regression parameters decreased; in the aforementioned model, the two parameters yielded PRSE $<5 \%$.

In contrast, in the total volume model $[\ln (V)$ $=\ln (a)+b \cdot \ln (D)+c \cdot \ln (H)+\varepsilon]$ fitted for $H$. alchorneoides, $D$ and $H$ were strongly correlated ( $r$ $=0.86, p<0.01)$ (Figure 4$)$. The collinearity (VIF $=5.24)$ inflated the standard error of the parameter associated with $\ln (H)$, the variable showing weaker relationship with the response variable. As a comparison, the parameter associated with $\ln (H)$ yielded PRSE $=33 \%$, while the parameter associated with $\ln (D)$ yielded PRSE $=5 \%$. The difference between the explained variation of $\ln (V)$ by collinear predictor variables is noticeable: $\mathrm{R}^{2 *}{ }_{\ln (D)}=0.57$ and $\mathrm{R}^{2 *}{ }_{\ln (H)}=0.43$ - the $\mathrm{R}^{2 *}$ was split between the surrogate variables. A model using only $\ln (D)$ would have yielded $\mathrm{R}^{2 *}=0.98$. This brief explanation might support the results regarding the model $\ln (V)=\ln (a)+b \cdot \ln (D)+\varepsilon$ as one of the best performances for total tree volume prediction for both species.

As stressed by Picard et al. (2015), collinearity should not overwhelm researchers, especially when dealing with relevant variables for volume or biomass prediction, such as $D$ and $H$. Collinearity between these variables implies that their regression parameters are not to be standalone interpreted, though rather as an ensemble. Our example might well represent the paradox of maintaining or not maintaining a given parameter when its PRSE > $25 \%$ or $30 \%$. Keeping the parameter associated with $\ln (H)$ in the model (even though presenting PRSE $=33 \%$ ) would be a reasonable decision, because for equal $D$ trees, $H$ will act as a correction variable-e.g., the greater the $H$, the larger the volume estimate by the model (Picard et al. 2015). Evidence in favor of keeping the $c$ parameter in the model is the significant difference $(F=8.9, p$ $=0.004)$ revealed by the ANOVA comparing the model $\ln (V)=\ln (a)+b \cdot \ln (D)+c \cdot \ln (H)+\varepsilon$ and the nested model $\ln (V)=\ln (a)+b \cdot \ln (D)+\varepsilon$ fitted for the total volume dataset of $H$. alchorneoides.

\section{BARK FACTORS}

For the 288 measured trees, the bark represented $16.6 \%(\mathrm{SD}=4.8 \%)$ of their total volume and $14.7 \%(\mathrm{SD}=4.8 \%)$ of their stem volume. The mean bark factors ranged from 0.798 to 0.858 , while presenting quite similar values (Table IV).

The mean paired differences between the observed and predicted inside bark volume were small (Table IV). Significant differences (nonetheless small) were found only for the stem volume of M. cinnamomifolia and H. alchorneoides. These results may validate the use of the calculated bark factors in mean inside bark volume estimation.

\section{CONCLUSIONS}

We may draw the main conclusions of this study as follows: (i) the overall quality of the models was satisfactory, and therefore they provide tailored 

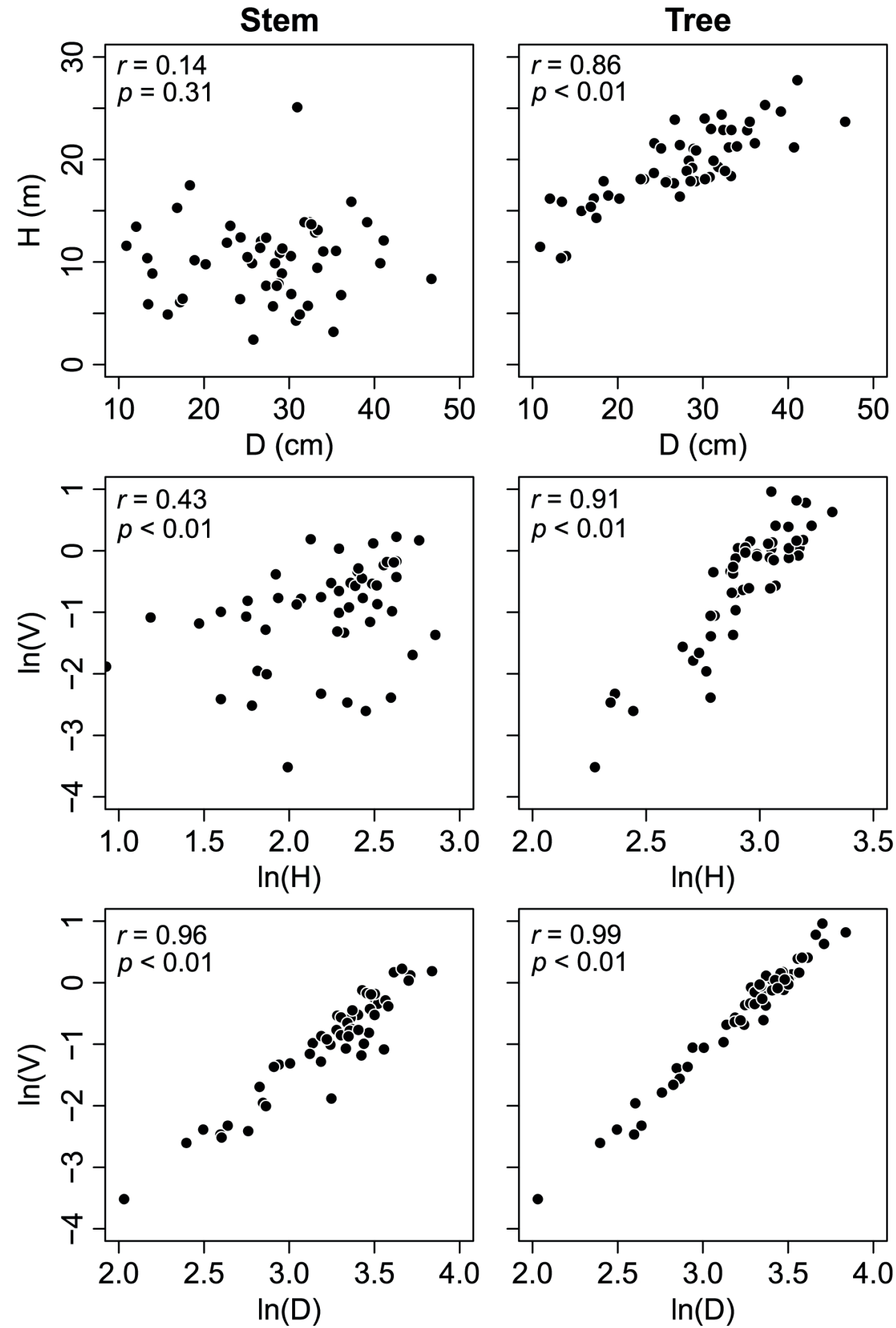

Figure 4 - Relationships between different predictor variables and stem and total volume of $H$. alchorneoides $(n=53)$. $r=$ Pearson's correlation coefficient. 
TABLE IV

Bark factors, mean paired differences between the observed total and stem inside bark volume and the predicted inside bark volume using the generic and species-specific models and bark factors.

\begin{tabular}{ccc}
\hline Species & $\begin{array}{c}\text { Bark factor } \\
(\mathrm{SD})\end{array}$ & $\begin{array}{c}\text { Mean difference } \\
( \pm 95 \% \mathrm{CI})\end{array}$ \\
\hline $\begin{array}{c}\text { Generic }(n=288) \\
\text { Total volume } \\
\text { Stem volume }\end{array}$ & $0.834(0.048)$ & $-0.0158^{\mathrm{ns}} \pm 0.0169 \mathrm{~m}^{3}$ \\
$\begin{array}{l}\text { M. cinnamomifolia } \\
(n=29)\end{array}$ & & \\
$\begin{array}{l}\text { Total volume } \\
\text { Stem volume }\end{array}$ & $0.858(0.029)$ & $-0.0271^{\mathrm{ns}} \pm 0.0378 \mathrm{~m}^{3}$ \\
$\begin{array}{l}H . \text { alchorneoides } \\
(n=53)\end{array}$ & $0.0033^{\mathrm{ns}} \pm 0.0079 \mathrm{~m}^{3}$ \\
$\quad \begin{array}{l}\text { Total volume } \\
\text { Stem volume }\end{array}$ & $0.831(0.036)$ & $-0.0203^{*} \pm 0.0184 \mathrm{~m}^{3}$ \\
\hline
\end{tabular}

ns - nonsignificant $(p \geq 0.05), *$ - significant $(p<0.05)$.

and useful volume estimation tools in forest management in the Southern Brazilian ERF; (ii) species-specific models performed just slightly better than generic models. Accordingly, it is clear that the additional effort in specific data collection does not pay off; (iii) $D$ single-predictor models are an acceptable solution due to the compromising issues regarding the operational measurement of $H$ in subtropical closed-canopy forests. Eventually, such models may even outperform more complex ones in the case of species with more regular architecture (e.g., M. cinnamomifolia); (iv) quantification of uncertainty in the estimation of regression parameters reveals critical information for model selection and validation; (v) bark factors applied together with volumetric models are effective mean inside bark volume estimation tools.

\section{ACKNOWLEDGMENTS}

We are grateful to the owner of the study area, Mr. Clemente Bisewiski, for the permission to execute the research. We are grateful to Eva Sevillano Marco for reviewing the manuscript regarding its general logical flow and English language. We are also grateful to Luiz Henrique Silva for reviewing the English language of the manuscript. The last author thanks the Conselho Nacional de Desenvolvimento Científico e Tecnológico (CNPq) for the awarded research grant (312075/2013-8).

\section{REFERENCES}

ALVARES CA, STAPE JL, SENTELHAS PC, GONÇALVES JLM AND SPAROVEK G. 2013. Köppen's climate classification map for Brazil. Meteor Z 22: 711-728.

ANDERSON-SPRECHER R. 1994. Model comparisons and $\mathrm{R}^{2}$. Am Stat 48: 113-117.

AVERY TE AND BURKHART HE. 2015. Forest measurements, $5^{\text {th }}$ ed., Waveland Press, $456 \mathrm{p}$.

BARRETO WF, LEÃO FM, MENEZES MC AND SOUZA D. 2014. Equação de volume para apoio ao manejo comunitário de empreendimento florestal em Anapu, Pará. Pesq Flor Bras 34: 321-330.

BASKERVILLE GL. 1972. Regression in the estimation of plant biomass. Can J For Res 2: 49-53.

BRAND MA, CUNHA AB, CARVALHO AF, BREHMER DR AND KÜSTER LC. 2013. Análise da qualidade da madeira e do carvão vegetal produzido a partir da espécie Miconia cinnamomifolia (De Candolle) Naudin (Jacatirãoaçu) na agricultura familiar, em Biguaçu, Santa Catarina. Sci For 41(99): 401-410.

BRANDEIS TJ, KUEGLER O AND KNOWE SA. 2005. Equations for merchantable volume for subtropical moist and wet forests of Puerto Rico. USDA Forest Service, Research paper SRS-39, $15 \mathrm{p}$.

CARVALHO AF, BRAND MA, NONES DL, MARCO FT, FRIEDERICHS F AND WEISE SMK. 2014. Propriedades físicas e energéticas da madeira e do carvão vegetal da espécie Hyeronima alchorneoides. Pesq Flor Bras 34: 257261.

CORADIN L, SIMINSKI A AND REIS A. 2011. Espécies nativas da flora brasileira de valor econômico atual ou potencial plantas para o futuro - Região Sul. Brasília: Ministério do Meio Ambiente, 934 p.

EMBRAPA. 2004. Solos do Estado de Santa Catarina. Rio de Janeiro: Embrapa, $721 \mathrm{p}$.

FANTINI AC, SIMINSKI A AND GAIO MF. 2016. Madeira de florestas secundárias em SC: nova fonte de renda para os agricultores. Agropecurária Catarinense 29: 15-18.

FELDPAUSCH ET AL. 2012. Tree height integrated into pantropical forest biomass estimates. Biogeosciences 9: 3381-3403.

FUNDAÇÃO S.O.S. MATA ATLÂNTICA. 2009. Atlas dos remanescentes florestais da Mata Atlântica, período 20052008. São Paulo: Fundação S.O.S. Mata Atlântica, 156 p. 
JARA MC ET AL. 2015. Guidelines for documenting and reporting tree allometric equations. Ann For Sci 72: 763768.

KLEIN RM. 1978. Mapa fitogeográfico do Estado de Santa Catarina. In: Reitz R (Ed), Flora Ilustrada Catarinense, Itajaí: Herbário Barbosa Rodrigues, 24 p.

KLEIN RM. 1980. Ecologia da flora e vegetação do Vale do Itajaí (continuação). Sellowia 32: 165-389.

MACHADO SA, FIGURA MA, SILVA LCR, TÉO SJ, STOLLE L AND URBANO E. 2008. Modelagem volumétrica para bracatinga (Mimosa scabrella) em povoamentos da Região Metropolitana de Curitiba. Pesq Flor Bras 56: 17-29.

MCROBERTS RE, CHEN Q, DOMKE GM, STÅHL G, SAARELA S AND WESTFALL JA. 2016. Hybrid estimators for mean aboveground carbon per unit area. For Ecol Manage 378: 44-56.

MONTAGNINI F AND JORDAN CF. 2005. Tropical forest ecology: the basis for conservation and management. Berlin: Springer, $295 \mathrm{p}$.

MOSER P AND OLIVEIRA LZ. 2017. Regressão aplicada à dendrometria: uma introdução e iniciação à linguagem R. Blumenau: Edifurb, 152 p.

NETER J, KUTNER MH, NACHTSHEIM CJ AND WASSERMAN W. 1996. Applied linear statistical models. Boston: McGraw-Hill Inc, 1396 p.

OLIVEIRA-FILHO AT, BUDKE JC, JARENKOW JA, EISENLOHR PV AND NEVES DRM. 2015. Delving into the variations in tree species composition and richness across South American subtropical Atlantic and Pampean forests. J Plant Ecol 8: 242-260.

PANDOLFO C, BRAGA HJ, SILVA JR VP, MASSIGNAN AM, PEREIRA ES AND THOMÉ VMR. 2002. Atlas climatológico do Estado de Santa Catarina. Florianópolis: EPAGRI, CD-ROM.

PICARD N, RUTISHAUSER E, PLOTON P, NGOMANDA A AND HENRY M. 2015. Should tree biomass allometry be restricted to power models? For Ecol Manage 353: 156163.

PICARD N, SAINT-ANDRÉ L AND HENRY M. 2012. Manual for building tree volume and biomass allometric equations: from field measurement to prediction. Montpellier: FAO, 215 p.

RIBEIRO MC, METZGER JP, MARTENSEN AC, PONZONI FJ AND HIROTA MM. 2009. The Brazilian Atlantic Forest: How much is left, and how is the remaining forest distributed? Implications for conservation. Biol Conserv 142: 1141-1153.
SANTOS AT, MATTOS PP, BRAZ EM AND ROSOT NC. 2012. Equação de volume e relação hipsométrica para plantio de Ocotea porosa. Pesq Flor Bras 32: 13-22.

SCHORN LA AND GALVÃO F. 2006. Dinânima da regeneração natural em três estágios sucessionais de uma Floresta Ombrófila Densa em Blumenau, SC. Floresta 36: 59-74.

SCHUCH C, SIMINSKI A AND FANTINI AC. 2008. Uso e potencial madeireiro do jacatirão-açu (Miconia cinnamomifolia (de Candolle) Naudin) no litoral de Santa Catarina. Floresta 38: 735-741.

SCOLFORO JR, OLIVEIRAAD AND ACERBI JÚNIOR FW. 2008. Equações de volume, peso de matéria seca e carbono para diferentes fisionomias da flora nativa. Lavras: Editora UFLA, $216 \mathrm{p}$.

SEGURA M AND KANNINEN M. 2005. Allometric models for tree volume and total aboveground biomass in a tropical humid forest in Costa Rica. Biotrop 37: 2-8.

SILESHI GW. 2014. A critical review of forest biomass estimation models, common mistakes and corrective measures. For Ecol Manage 329: 237-254.

SILVA DA, KLITZKE AR AND ULLER HF. 2015. Alterações na estrutura fitossociológica do estrato arbóreo causadas pelo corte seletivo em uma área de manejo florestal em Santa Catarina. In: Anais $6^{\circ}$ Simpósio Latino-Americano Sobre Manejo Florestal, Santa Maria: UFSM, p. 77-83.

SIMINSKI AAND FANTINI AC. 2004. Classificação da Mata Atlântica do litoral catarinense em estádios sucessionais: ajustando a lei ao ecossistema. Floresta e Ambiente 11: 20-25.

SIMINSKI A, SANTOS KL AND WENDT JGN. 2016. Rescuing agroforestry as strategy for agriculture in Southern Brazil. J For Res 27: 739-746.

TEMESGEN H, AFFLECK D, POULDEL K, GRAY A AND SESSIONS J. 2015. A review of the challenges and opportunities in estimating above ground forest biomass using tree-level models. Scand J For Res 30: 1-10.

VIBRANS AC, MCROBERTS RE, MOSER P AND NICOLETTI AL. 2013. Using satellite image-based maps and ground inventory data to estimate the area of the remaining Atlantic forest in the Brazilian state of Santa Catarina. Remote Sens Environ 130: 87-95.

VIBRANS AC, MOSER P, OLIVEIRA LZ AND MAÇANEIRO JP. 2015. Generic and specific stem volume models for three subtropical forest types in southern Brazil. Ann For Sci 72: 865-874.

WAGENMAKERS EJ AND FARRELL S. 2004. AIC model selection using Akaike weights. Psychon Bull Rev 11: 192-196. 